\title{
Survey on Informatization level for developing Customized Contents enhancing ICT capability - focused on Life University in Cambodia
}

\author{
Hwa-Jin Park*
}

\begin{abstract}
ICT capacity building education in developing countries with poor infrastructure is a solution to help solve ICT gaps and improve economic performance. However, there is a clear difference between countries' geographical and industrial level in terms of geographical and industrial aspects. Therefore, it is necessary to design customized educational contents for each country according to the status of various industries in each country rather than uniform and unilateral ICT capacity building education. This should be followed by a basic understanding of the current situation. The purpose of this study is to identify the level of ICT technology and curricula for female students at Life University of Cambodia among developing countries, and to find out the subjects related to industry in that region and to propose policies for continuous operation.
\end{abstract}

Keywords: ICT empowerment, customized contents. ICT gap

\section{맞춤형 ICT역량강화 콘텐츠개발을 위한 정보화 실태조사 - 캄보디아 라이프대학을 중심으로}

박화진*

요 약

인프라가 열악한 개도국에서의 ICT역량 강화교육은 ICT 격차해소 및 경제력 향상에 도움을 주는 해 결책이라고 할 수 있다. 하지만 국가의 지리적, 산업적인 면에서 다양한 정보화 수준차이가 분명히 존재 하므로, 일률적이며 일방적인 ICT 역량강화교육보다는 각 국가의 다양한 산업수요현황에 따라 국가별 맞춤형 교육 콘텐츠 설계를 할 필요가 있으며 이를 위한 기초적인 현황 파악이 선행되어야 한다. 본 연 구는 개발도상국 중 캄보디아 라이프대학교 여대생들을 대상으로 현지 ICT 기술수준 및 교육현황을 파 악하고 지역별 산업과 연계된 과목을 발굴하며 지속적인 운영을 위한 정책등을 제언하는 것을 목표로 한다.

키워드: ICT 역량강화, 맞춤형 콘텐츠, ICT 격차

\section{Introduction}

※ Corresponding Author: Park, Hwa Jin Received: December 05, 2016

Revised: December 28, 2016

Accepted: December 30, 2016

* Sookmyung Women's University IT Engineering

Tel: +82-2-710-9204, Fax: +82-2-710-9704

email:phj2000@sm.ac.kr

$\square$ This research was funded by Korean Ministry of Education as a part of Sookmyung UNESCO

-UNITWIN Program (2-1601-0007)

\subsection{Background}

As the recent ICT technology has been developed and fused with all fields, it has become a necessary technology to be sure to know without major or minor.

Just as the information gap is linked to the disparity in the level of jobs and the gap between the rich and the poor, the ICT gap is not limited to that field, but the economy and the whole society are deeply affected. The 
digital divides that can occur in the same country are socioeconomic status, gender, life stage, and Region[1].

Therefore, efforts to reduce the digital divides between countries and social classes are very necessary. In this sense, ICT capacity-building education in developing countries with poor infrastructure is a solution to resolve the ICT gap and improve economic efficiency[2]. However, because there are various differences in information level in the country's geographical and industrial aspects, it is necessary to design customized educational contents according to the state of various industries in each country rather than uniform and unilateral ICT capacity building education. Therefore, in order to design contents according to the situation of the country among the various ICT technologies considering infrastructure and industrial demand capacity, basic investigation must be preceded. The purpose of this study is to identify the level of ICT technology and curricula for female students at Life University of Cambodia among developing countries, and to find out the subjects related to industry in that region and to propose policies for continuous operation.

\section{2 research method}

This study will be carried out in cooperation with the Life University of Cambodia, and the overall management of the questionnaire preparation and analysis will be conducted in Korea and the Cambodia Life University will cooperate in collecting and coding data by contacting the questionnaires.

In the questionnaire survey, which is a quantitative survey of the present study, there are two categories: female students (about 80 students) and public officials / teachers (about 20 people). We surveyed the current situation of school policy and curriculum including not only students but also public officials and teachers.

\section{Survey}

\subsection{Considerations for questionaire}

Because the level of informatization varies from country to country, it is necessary to select the appropriate region to find customized ICT education contents that match local characteristics rather than uniform contents. In this study, Life University of Cambodia was selected as the target. In order to know the current status of the area, you should include the following matters.

1) ICT Infrastructure Status

- computer / Internet usage and speed

2) Device accessibility

- computers, mobile phones,

- smart devices

3) Application Skills level

4) Programming coding skills level

5) Employment related applications

6) ICT life-friendliness

7) Local ICT industry

8) Student employment status

9) Relationship between ICT technology hold and employment / promotion

10) ICT curriculum for secondary and tertiary education institutions

11) Government support for ICT policy

\subsection{Survey responder Configuration}

The subjects were divided into the following grades and majors. Of the 83 students, 29 were freshman (34.9\%), 11 were sophomore (13.3\%), 27 were junior (32.5\%), and 9 were senior (10.8\%) (8.4\%). They are well distributed in each grade including 7 leave of absence(8.4\%).

In addition, respondents' major were classified into six major categories. Liberal art \& social science 14 people (16.9\%), science \& engineering 4 people (4.8\%), Economics \& Business administration 14 people (16.9\%), 
human ecology 2 people (2.4\%), music \& fine arts 1 person (1.2\%), medical \& pharmacy 37 (44.6\%) and others 11 (13.3\%).

\section{Survey results and analysis}

\subsection{Survey results}

\subsubsection{Accessibility of ICT equipment}

Accessibility means how often or how easily an ICT device can be used. Higher accessibility tends to increase the usability of ICT-related apps and application software.

$<$ Table 1> shows that many students use or own a mobile phone rather than a $\mathrm{PC}$, and handheld devices such as a smart phone or iPAD are used or owned by very few students.

\begin{tabular}{|c|c|c|c|c|}
\hline & PC & $\begin{array}{c}\text { Mobile } \\
\text { phone }\end{array}$ & $\begin{array}{c}\text { Handheld } \\
\text { device }\end{array}$ & None \\
\hline $\begin{array}{c}\text { available } \\
\text { decvices } \\
\text { (Resppnses: } \\
110)\end{array}$ & $\begin{array}{c}39 \text { persons } \\
(35.5 \%)\end{array}$ & $\begin{array}{c}65 \text { persons } \\
(59.1 \%)\end{array}$ & $\begin{array}{c}6 \text { persons } \\
(5.5 \%)\end{array}$ & 0 \\
$\begin{array}{c}\text { Owned } \\
\text { devices } \\
\text { (Responses: } \\
106)\end{array}$ & $\begin{array}{c}32 \text { persons } \\
(30.2 \%)\end{array}$ & $\begin{array}{c}67 \text { persons } \\
(63.2 \%)\end{array}$ & $\begin{array}{c}4 \text { persons } \\
(3.8 \%)\end{array}$ & $\begin{array}{c}3 \text { person } \\
\text { S } \\
(2.8 \%)\end{array}$ \\
\hline
\end{tabular}

$<$ table 1> Device accessibility

\subsubsection{Purpose of ICT device / Internet} use

According to the survey results, the main purpose of using ICT devices is communication $(56.4 \%)$, followed by education (41.9\%). Other purposes such as entertainment, business, programing, and others are very similar, which are 14\%, 11\%, 9\%, and $11 \%$. This result is related with the largest number of mobile phone devices available in <table $1>$. The infrastructure environment of smart devices such as smartphones and iPADs is very poor and the frequency of use of apps used in smart devices is very low. They are not in circumstances in using smart devices, so that they use only in mobile phone to communicate.

For the purposes of using the Internet, 42 persons $(33 \%)$ of $\mathrm{e}$-learning were the most followed by Online communication 36 pers. (28\%) and access information 29 pers. (23\%). (9\%), public $\mathrm{e}^{-}$service 5 (4\%), others $3(2 \%)$ and $\mathrm{e}^{-}$-commerce 1 (1\%). This order is analyzed because Cambodia is not equipped with online service for the internet industry or the public, so it is not easy to get online service such as bank, payment system, and online shopping mall.

\subsubsection{Computer/Internet Literacy Level}

In order to determine the level of respondents' use of the computer / Internet objectively, we defined the level of computer and internet use as shown in $\langle$ Table $2>$.

\begin{tabular}{|c|c|c|}
\hline $\begin{array}{c}\text { Literacy } \\
\text { level }\end{array}$ & $\begin{array}{l}\text { Computer related } \\
\text { skills }\end{array}$ & Internet related skills \\
\hline $\begin{array}{l}\text { No } \\
\text { skill }\end{array}$ & $\begin{array}{l}\text { I don't know the } \\
\text { functionalities of } \\
\text { my device and I } \\
\text { cannot use my ICT } \\
\text { device. }\end{array}$ & $\begin{array}{l}\text { I do not know how } \\
\text { to use the internet. }\end{array}$ \\
\hline $\begin{array}{l}\text { Basic } \\
\text { skill }\end{array}$ & $\begin{array}{l}\text { Copying or moving } \\
\text { a file or folder, } \\
\text { Using copy and } \\
\text { paste tools to } \\
\text { duplicate or move } \\
\text { information within a } \\
\text { document }\end{array}$ & $\begin{array}{l}\text { Participating in social } \\
\text { networks, finding } \\
\text { information about } \\
\text { goods \& services }\end{array}$ \\
\hline $\begin{array}{l}\text { Interm } \\
\text { ediate- } \\
\text { low }\end{array}$ & $\begin{array}{l}\text { Sending e-mails } \\
\text { with attached files } \\
\text { (e.g. document, } \\
\text { picture, video) }\end{array}$ & $\begin{array}{l}\text { Accessing chat sites, } \\
\text { blogs, newsgroups or } \\
\text { online discussions; } \\
\text { playing or } \\
\text { downloading games; } \\
\text { streaming or } \\
\text { downloading images, } \\
\text { movies, videos or } \\
\text { music }\end{array}$ \\
\hline $\begin{array}{l}\text { Interm } \\
\text { ediate- } \\
\text { mediu } \\
\text { m }\end{array}$ & $\begin{array}{l}\text { Using basic } \\
\text { arithmetic } \\
\text { formulas in a } \\
\text { spreadsheet }\end{array}$ & $\begin{array}{l}\text { Purchasing or ordering } \\
\text { goods or services }\end{array}$ \\
\hline $\begin{array}{l}\text { Interm } \\
\text { ediate- } \\
\text { advanc } \\
\text { ed }\end{array}$ & $\begin{array}{l}\text { Connecting and } \\
\text { installing new } \\
\text { devices (e.g. } \\
\text { modem, camera, } \\
\text { printer), Transferring } \\
\text { files between a } \\
\text { computer and other } \\
\text { devices }\end{array}$ & $\begin{array}{l}\text { Video conferencing, } \\
\text { copyright privacy, } \\
\text { uploading } \\
\text { self/user-created } \\
\text { content to a website } \\
\text { to be shared, } \\
\text { managing personal } \\
\text { homepage }\end{array}$ \\
\hline $\begin{array}{l}\text { Advanc } \\
\text { ed }\end{array}$ & $\begin{array}{l}\text { Writing a } \\
\text { computer program } \\
\text { using a specialized } \\
\text { programming } \\
\text { language }\end{array}$ & $\begin{array}{l}\text { Building personal } \\
\text { homepage with } \\
\text { programming language } \\
\text { (e.g. html, java script) }\end{array}$ \\
\hline
\end{tabular}

$<$ Table 2> Definition of Literacy Level

The results of the question are shown in $<$ Table $3>$. 


\begin{tabular}{|l|c|c|}
\hline \multicolumn{1}{|c|}{$\begin{array}{c}\text { Literacy } \\
\text { level }\end{array}$} & $\begin{array}{c}\text { Computer } \\
\text { related skills }\end{array}$ & $\begin{array}{c}\text { Internet related } \\
\text { skills }\end{array}$ \\
\hline No skill & $\begin{array}{c}15 \text { pers. } \\
(18.1 \%)\end{array}$ & 10pers. (12\%) \\
\hline Basic skill & $\begin{array}{c}29 \text { pers. } \\
(34.9 \%)\end{array}$ & 26pers. (31.3\%) \\
\hline $\begin{array}{l}\text { Intermediate-I } \\
\text { ow }\end{array}$ & $\begin{array}{c}21 \text { pers. } \\
(25.3 \%)\end{array}$ & 24pers. (28.9\%) \\
\hline $\begin{array}{l}\text { Intermediate- } \\
\text { medium }\end{array}$ & $\begin{array}{c}15 \text { pers. } \\
(18.1 \%)\end{array}$ & 18pers. (21.7\%) \\
\hline $\begin{array}{l}\text { Intermediate- } \\
\text { advanced }\end{array}$ & 2pers. (2.4\%) & 3pers. (3.6\%) \\
\hline Advanced & 1pers. (1.2\%) & 2pers. (2.4\%) \\
\hline Total & 83pers. (100\%) & 83pers. (100\%) \\
\hline
\end{tabular}

$<$ Table 3> Results of Literacy Level

3.1.4 survey of Course ICT subjects / programs that they can use / ICT related subjects that they want to learn more

Most of the students took classes of word processing, spreadsheet and presentation, which are basic elements of office work, and also selected word processing, spreadsheet, and presentation as programs which she can use well. Many of them also chose word processing as a subject to want to learn more, and some selected SNS applications and internet applications as their preference .

The reason why the answers to the different questions are similar results from that the three programs, word processing, spreadsheet, and presentation, are basically the most used in companies and industries. A lot of students took these courses which results in that they use these programs well and many students still want to take the courses to learn more. It can be also interpreted that many students who took the program but want to learn more advanced skills.

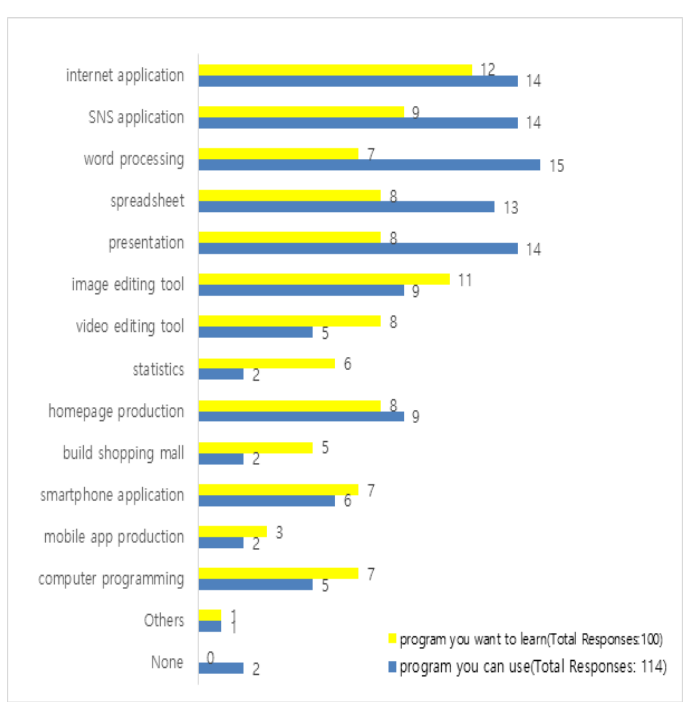

(Figure 1) Comparison between programs that they can use / ICT related subjects that they want to learn more

\subsubsection{ICT Learning Motivation}

ICT learning motivation was the most common, with 49 (33.6\%) being "helpful for the job", but 45 (30.8\%) were " (12.3\%), 14 $(9.6 \%)$ were "in need of daily life" and 10 (6.8\%) were "curious", and "because they are regular subjects" and "others" 6 (4.1\%) and 4 (2.7\%) were selected.

\subsubsection{Field of employment / Relation between ICT capability and employment}

Employment fields of after graduation are distributed in various, which are similar to their major fields. More than half of them came from health care 38 pers. (42.2\%) and management/finance 20pers, (22.2\%). Other fields are culture and arts, journalism 11 pers. (11.2\%), marketing 10 pers. (11.1\%), IT and communications 6 pers. (6.7\%).

In addition, to the question "How computer skills can you get a job?", 67 pers.(87\%) selected "a lot", 11 pers. (13.3\%) answered "some", 4 pers. (4.8\%) "a little", and 1 pers. $(1.2 \%)$ "none". In other words, it is 
investigated that most of them were ICT skills are helpful to get a job.

To the question "Choose programs that will specifically help you get a job", "Homepage production"(36), "word processing" (35), "presentation" (29) and "spread sheet" (28) are selected in order. Therefore, it can be analyzed that homepage related industry is emerging recently in Cambodia.

\subsubsection{Influence of ICT capacity on}

Economic Power / Self-willingness

In the case of ICT capacity, 55 pers. (66.3\%) who answered "a lot" and 20 pers. (24.1\%) "some" were considered to have influence on promotion or salary. To the question "Is there an intention to increase ICT capacity?", 56 pers. (65.7\%) who answerd "a lot" and 17 pers. (20.5\%) "some", were thought to have intents.

\subsubsection{Government support for strengthenin} -g ICT capacity

In the question "Do you think the government is helping University to learn ICT?", "A lot" was selected by 44 pers. (53\%) and "some" was selected by 19 pers. (22.9\%), This means that more than half think there is the government's support.

\subsection{Analysis and Summary}

The ICT infrastructure environment at Cambodia Life University is very poor and the internet speed is very slow, so students can not use various contents. Therefore, it is very rare for students to use smart devices such as modern smart phones and tablet PCs, and most of them use mobile phones only for text message and telephone purpose. In the case of civil servants / teachers, there was a little more use of smart devices than student respondents.

The applications students are learning at the school are very basic applications, such as word processing and presentation. In some cases, there has been a demand for applications such as homepage creation and image editing. Therefore, based on the industrial status of Cambodia, application training courses that can be linked to employment should be developed rather than new technology applications of the latest smart devices such as smart app, ubiqutous, or IOT etc.

One of the purposes for students to use the Internet is online education. At present, only ICT theory education thru on-line is carried in accordance with the actual situation, but it seems more urgent to install the infrastructure including equipment capable of practicing environment, considering the characteristics of ICT education that needs practice.

Students and surveyed people think ICT class is helpful for employment and study at university, and are very willing to learn a new ICT subject. They also think that ICT education will help a lot in employment or promotion if the capacity is increased, and it is also helpful when working in school or at work.

\section{Conclusion and Future research}

This study is a research that selects the appropriate area and investigates the present situation to find customized ICT contents suitable for local characteristics rather than uniform ICT education because the level of informatization varies by country.

As a result, we concluded that it is appropriate to develop homepage building subject and image editing subject with high demand related to employment in Cambodia Life University. In addition, local students are dependent on online lectures only, so practice is not performed even though they are 
practical courses. Therefore, it is necessary to try to make textbooks and lectures considering that it is a practical course when developing educational contents.

The follow-up process of this study will make a general process model to identify appropriate informatization level and its related ICT contents. Developing countries continue to increase. Grouping in several steps according to the region and development situation can reduce the time and effort to find out the appropriate content development.

Acknowlodgement I would like to express my gratitude to Shin Won-seon, a researcher who helped me fill out the questionnaire.

\section{References}

[1] W. Chen, B. Wellman, "The global digital dividewithin and between countries," IT\&Society, Vol.1, No.7, pp.18-25, 2004

[2] H. Lee, "Study on the effect of official development assistance on the global digital divide: with a focus on ICT sector," Ph.D. dissertation, KyungHee Univ. Korea, 2016

[3] H. Lee, "A study on the diagnostic model of cross-na tional digital divide," J.of IT\&A, Vol. 11, No. 1, pp.99 -111, March 2014

[4] M. Yoon, D. Kim. "A study of development and mana gement on ASEAN women's ICT development inde $\mathrm{x}$ and measurement," The J. of the Institute of intern et, broadcasting and communication, Vol. 16, No.4, pp.181-187, 2016

[5] S. Sim,"A study on the IT Cooperation by the Global IT Indexes of Asian 7 contries," Review of Eurasian Studies, Vol 4, No.2 pp.1-15, 2007

[6] Y.Kim,"The analysis on actual conditions of Korean e-Learning international consulting," thesis of The graduate school of educational policy abd administra tion Korea National Uiversity of Education, 2009
[7] Y.Park, J.Han, K.Bang,"A study on the informatizati on index of education for revitalizing ICT," J. of Digi tal Contents, Vol 3, No.1, pp.11-22, 2002

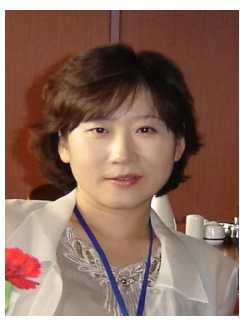

박 화 진

2000 현재 : 숙명여자대학교 공과대학 IT공학과 교수 관심분야 : 컴퓨터 그래픽, 가상현실, 게임, 콘텐츠기획, 영상인식
1989년 : 숙명여자대학교 대학원 (전산학석사)

1997년 : 미 아리조나주립대(공학 박사)

998년 : 삼성 SDS 연구원 
[Appendix] Questionnaire for female students at Cambodia Life University

\begin{tabular}{|c|c|c|}
\hline No. & \multicolumn{2}{|r|}{ Contents } \\
\hline 1 & \multicolumn{2}{|c|}{ Name of University, Country } \\
\hline 2 & \multicolumn{2}{|c|}{ What grade are you in? } \\
\hline 3 & \multicolumn{2}{|c|}{ What is your major? } \\
\hline 4 & \multicolumn{2}{|c|}{ Which ICT devices do you use? } \\
\hline 5 & \multicolumn{2}{|c|}{ Which ICT devices do you own? } \\
\hline 6 & \multicolumn{2}{|c|}{ What is/are your purpose(s) of using the ICT device? } \\
\hline 7 & \multicolumn{2}{|c|}{ What is/are your purpose(s) of using the Internet? } \\
\hline 8 & \multicolumn{2}{|c|}{ What is your Computer Literacy level? } \\
\hline 9 & \multicolumn{2}{|c|}{ What is your Internet Literacy level? } \\
\hline 10 & \multicolumn{2}{|c|}{$\begin{array}{l}\text { Which of the computer-related course(s) have you } \\
\text { taken in college? }\end{array}$} \\
\hline 11 & \multicolumn{2}{|c|}{ Which of the program(s) can you use? } \\
\hline 12 & \multicolumn{2}{|c|}{$\begin{array}{l}\text { Where have you learned your computer skills other } \\
\text { than in college? }\end{array}$} \\
\hline & \multicolumn{2}{|c|}{$\begin{array}{l}12-1 \text { What is the reason for not learning computer } \\
\text { skill(s)? }\end{array}$} \\
\hline 13 & \multicolumn{2}{|c|}{ What is/are the program(s) do you want to learn? } \\
\hline 14 & \multicolumn{2}{|c|}{ What is/are your reason(s) to learn? } \\
\hline \multirow[t]{2}{*}{15} & \multicolumn{2}{|c|}{$\begin{array}{l}\text { Are you willing to take a computer related subject, } \\
\text { which you have chosen in No. } 13 \text { question, if it is } \\
\text { open as a regular course in your university? }\end{array}$} \\
\hline & $15-1$ & If NOT, what is the reason? \\
\hline 16 & \multicolumn{2}{|c|}{$\begin{array}{l}\text { In which field(s) do you want to work after college } \\
\text { graduation? }\end{array}$} \\
\hline \multirow{3}{*}{17} & \multicolumn{2}{|c|}{$\begin{array}{l}\text { Do you think the learning computer skills will help } \\
\text { finding jobs? }\end{array}$} \\
\hline & $17-1$ & $\begin{array}{l}\text { Which program(s) help(s) finding } \\
\text { employment? }\end{array}$ \\
\hline & $17-2$ & If NOT, why do you think it is not helpful? \\
\hline 18 & \multicolumn{2}{|c|}{$\begin{array}{l}\text { Do you think ICT capacity will influence your } \\
\text { income? }\end{array}$} \\
\hline 19 & \multicolumn{2}{|c|}{$\begin{array}{l}\text { How much are you willing to enhance your ICT } \\
\text { capacity? }\end{array}$} \\
\hline 20 & \multicolumn{2}{|c|}{$\begin{array}{l}\text { Do you think the government provides support for } \\
\text { building women's ICT capacity? }\end{array}$} \\
\hline
\end{tabular}

